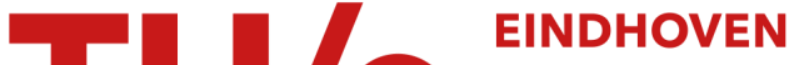 UNIVERSITY OF TECHNOLOGY
}

\section{Characterization of gamma-alumina-supported molybdenum oxide and tungsten oxide : reducibility of the oxidic state versus hydrodesulfurization activity of the sulfided state}

\author{
Citation for published version (APA): \\ Thomas, R., Oers, van, E. M., Beer, de, V. H. J., Medema, J., \& Moulijn, J. A. (1982). Characterization of \\ gamma-alumina-supported molybdenum oxide and tungsten oxide : reducibility of the oxidic state versus \\ hydrodesulfurization activity of the sulfided state. Journal of Catalysis, 76(2), 241-253. \\ https://doi.org/10.1016/0021-9517\%2882\%2990255-X, https://doi.org/10.1016/0021-9517(82)90255-X
}

DOI:

10.1016/0021-9517\%2882\%2990255-X

10.1016/0021-9517(82)90255-X

Document status and date:

Published: 01/01/1982

\section{Document Version:}

Publisher's PDF, also known as Version of Record (includes final page, issue and volume numbers)

\section{Please check the document version of this publication:}

- A submitted manuscript is the version of the article upon submission and before peer-review. There can be important differences between the submitted version and the official published version of record. People interested in the research are advised to contact the author for the final version of the publication, or visit the $\mathrm{DOI}$ to the publisher's website.

- The final author version and the galley proof are versions of the publication after peer review.

- The final published version features the final layout of the paper including the volume, issue and page numbers.

Link to publication

\footnotetext{
General rights

- You may freely distribute the URL identifying the publication in the public portal. follow below link for the End User Agreement:

www.tue.nl/taverne

\section{Take down policy}

If you believe that this document breaches copyright please contact us at:

openaccess@tue.nl

providing details and we will investigate your claim.
}

Copyright and moral rights for the publications made accessible in the public portal are retained by the authors and/or other copyright owners and it is a condition of accessing publications that users recognise and abide by the legal requirements associated with these rights.

- Users may download and print one copy of any publication from the public portal for the purpose of private study or research.

- You may not further distribute the material or use it for any profit-making activity or commercial gain

If the publication is distributed under the terms of Article 25fa of the Dutch Copyright Act, indicated by the "Taverne" license above, please 


\title{
Characterization of $\gamma$-Alumina-Supported Molybdenum Oxide and Tungsten Oxide; Reducibility of the Oxidic State versus Hydrodesulfurization Activity of the Sulfided State
}

\author{
R. Thomas,,$*$ E. M. van Oers,$\dagger$ V. H. J. de Beer, $\dagger$ J. Medema $\ddagger$ And \\ J. A. MouliJn ${ }^{*, 1}$

\begin{abstract}
*Institute for Chemical Technology, University of Amsterdam, Plantage Muidergracht 30, 1018 TV Amsterdam, The Netherlands, + Laboratory for Inorganic Chemistry and Catalysis, Eindhoven University of Technology, Postbus 513, 5600 MB Eindhoven, The Netherlands, and $\ddagger$ Prins Maurits Laboratory TNO, Postbus 45, 2280 AA Rijswijk, The Netherlands
\end{abstract}

Received December 2, 1980; revised December 4, 1981

\begin{abstract}
Thiophene hydrodesulfurization and butene hydrogenation have been determined for $\mathrm{MoO}_{3} / \gamma$ $\mathrm{Al}_{2} \mathrm{O}_{3}, \mathrm{WO}_{3} / \gamma-\mathrm{Al}_{2} \mathrm{O}_{3}$, and $\mathrm{Re}_{2} \mathrm{O}_{7} / \gamma-\mathrm{Al}_{2} \mathrm{O}_{3}$ catalysts, using a micro-flow reactor operating at atmospheric pressure. Catalysts have been prepared by various methods, viz., ion exchange, gas-phase adsorption, dry and wet impregnation of $\gamma-\mathrm{Al}_{2} \mathrm{O}_{3}$ as well as impregnation of boehmite. The catalysts have been prepared on a surface coverage basis.

The catalysts were characterized by X-ray diffraction, surface area and pore volume measurements, and temperature-programmed reduction (TPR). $\mathrm{MoO}_{3} / \gamma-\mathrm{Al}_{2} \mathrm{O}_{3}$ and $\mathrm{WO}_{3} / \gamma-\mathrm{Al}_{2} \mathrm{O}_{3}$ catalysts prepared by dry and wet impregnation give essentially the same results.

A correlation exists between the reducibility of oxidic $\mathrm{MoO}_{3} / \gamma-\mathrm{Al}_{2} \mathrm{O}_{3}$ and $\mathrm{WO}_{3} / \gamma-\mathrm{Al}_{2} \mathrm{O}_{3}$ catalysts prepared by dry and wet impregnation, and the hydrodesulfurization activity of the sulfided samples. The higher the reducibility, the higher the hydrodesulfurization activity. This correlation also holds for $\mathrm{MoO}_{3} / \gamma-\mathrm{Al}_{2} \mathrm{O}_{3}$ catalysts prepared by other methods, viz., ion exchange, gas-phase adsorption, and impregnation of boehmite, and for $\mathrm{Re}_{2} \mathrm{O}_{7} / \gamma-\mathrm{Al}_{2} \mathrm{O}_{3}$ catalysts prepared by dry impregnation.

Butene hydrogenation activity of sulfided $\mathrm{MoO}_{3} / \gamma-\mathrm{Al}_{2} \mathrm{O}_{3}$ and $\mathrm{WO}_{3} / \gamma-\mathrm{Al}_{2} \mathrm{O}_{3}$ catalysts also correlates with reducibility. This correlation is qualitatively the same as that found for hydrodesulfurization. For $\mathrm{Re}_{2} \mathrm{O}_{7} / \gamma-\mathrm{Al}_{2} \mathrm{O}_{3}$ catalysts this is not the case. The ratio between hydrodesulfurization activity and hydrogenation activity decreases in the order $\mathrm{W} \rightarrow \mathrm{Mo} \rightarrow \mathrm{Re}$.

TPR is a time-saving screening technique for unpromoted well-dispersed hydrodesulfurization catalysts.
\end{abstract}

\section{INTRODUCTION}

Supported oxides and sulfides of molybdenum and tungsten are well known for catalyzing a great variety of reactions. The developments in petroleum- and coal-refining technology in the last two decades have brought the application of the sulfides for reactions referred to as hydroprocessing to a high level of economic importance. Some examples of these reactions are desulfurization, denitrogenation, deoxygenation, hydrogenation, and hydrocracking of petroleum compounds. During hydrodesul-

${ }^{1}$ Author to whom correspondence should be addressed. furization extra hydrogen is always consumed due to the hydrogenation of unsaturated hydrocarbons. This is often undesirable, since it leads to loss of expensive hydrogen. On the other hand, in the future, hydrogenation and hydrocracking will become more important because the need for clean fossil fuels has extended to heavy petroleum fractions and to coal. As a result, there is great demand for catalysts having better properties for the hydrogenation of these heavy feeds and of coal and coal-derived liquids. In this respect W-based catalysts have been reported to have better properties than Mo-based catalysts $(I)$. Therefore in this study $\mathrm{MoO}_{3} / \gamma-\mathrm{Al}_{2} \mathrm{O}_{3}$ and 
$\mathrm{WO}_{3} / \gamma-\mathrm{Al}_{2} \mathrm{O}_{3}$ have been compared. It must be emphasized that whereas industrial catalysts usually contain Mo and Co or W and $\mathrm{Ni}$, only unpromoted catalysts have been studied here.

As a result of a considerable number of studies a reasonable model of the structure of the oxidic precursors of unpromoted catalysts has been achieved (2-24). It is clear that, in general, the oxidic catalysts consist of a monolayer of molybdenum or tungsten compounds on the carrier. It has been suggested by Gajardo (17) that also multilayers can be formed. At high transition metal contents bulk compound formation has been observed, viz., molybdenum or tungsten trioxide and aluminum molybdate or tungstate.

It has been reported that the transition metal content of the catalysts influences the relative amounts of the various species $(8,12,13,21)$. This is the reason why in this study the active-phase concentration has been varied to a large extent. In order to compare the catalysts correctly, the variation in metal compound concentration expressed as the average number of metal atoms per unit area of the support is kept the same for all series. The catalysts have been prepared via dry and wet impregnation of a high-purity $\gamma$-alumina; the drying and calcining procedures were the same for all catalysts.

In general, the aim of structural studies is to correlate structural information with catalytic activity. Such an effort seems quite reasonable when the structure of the catalysts does not change essentially during pretreatment and catalytic action. For $\mathrm{MoO}_{3} / \gamma-\mathrm{Al}_{2} \mathrm{O}_{3}$ and $\mathrm{WO}_{3} / \gamma-\mathrm{Al}_{2} \mathrm{O}_{3}$ catalysts this applies perhaps to reactions like metathesis and polymerization of olefins. However, in the case of hydrodesulfurization the situation is different. It is well known that due to reduction and sulfidation the monolayer is more or less destroyed. Consequently the structure of sulfided catalysts should preferably be studied under actual (in situ) reaction conditions. Mainly due to experimental limitations such in situ studies of the structure of sulfided catalysts have been performed considerably less often than studies on the oxidic analogues. Therefore, it is particularly useful to develop a technique, which, although applied to oxidic catalysts, gives information on the catalytic properties of the corresponding sulfided systems. Since, during the transformation of the oxidic precursor into the sulfided state, reduction is essential, it is logical to study the reduction characteristics of the oxidic catalysts.

In principle reducibility can be determined in several ways. The most common techniques are isothermal reduction and temperature-programmed reduction (TPR). TPR gives essentially a fingerprint of the reducibility and reflects the reduction kinetics of the system studied. Consequently it is to be expected that results will be influenced by variations in experimental conditions such as the nature of the reducing medium, preconditioning of the sample, and the heating rate. However, when each experiment is performed under the same conditions, as has been the case here, TPR gives useful information on the reduction characteristics of comparable samples. $\mathrm{Nag}$ et al. (25) have characterized hydroprocessing catalysts by temperature-programmed desorption (TPD), reduction, and sulfiding. They have shown that these techniques give useful information on inter alia the sulfiding step. However, the correlation between reducibility and hydrodesulfurization activity was not systematically studied.

In the present study reduction data, obtained from TPR experiments, are combined with activity data (thiophene hydrodesulfurization and butene hydrogenation) of the sulfided catalysts. It will be shown that a correlation exists between the reducibility of the oxidic precursors and the catalytic activity of the sulfided catalysts. Also Mo-based catalysts prepared by other methods (liquid-phase adsorption, gasphase adsorption, impregnation of boehmite) and some $\mathrm{Re}_{2} \mathrm{O}_{7} / \gamma-\mathrm{Al}_{2} \mathrm{O}_{3}$ catalysts 
(having completely different reduction characteristics (26)) have been studied, to investigate a more general validity of this correlation.

It is to be expected that reduction kinetics for highly dispersed monolayer-type and ill-dispersed bulk or bulk-like species will not be the same. In this paper, therefore, only catalysts containing highly dispersed active material are considered. The same argument holds for catalysts which contain more than one metal, e.g., $\mathrm{Co}-\mathrm{Mo} / \gamma-\mathrm{Al}_{2} \mathrm{O}_{3}$ catalysts. For this type of catalyst, cobalt species, being easily reducible, probably accelerate reduction of the molybdenum species $(27,28)$. The influence of these parameters, variation in the degree of dispersion and promoting, is presently under investigation.

It is recognized that the conditions applied for testing catalytic activity are certainly different from industrial conditions. However, the application of a small molecule like thiophene is preferable in this fundamental study, because the structural features are obtained with TPR, a technique measuring the reactivity towards the small molecule hydrogen.

\section{E XPERIMENTAL}

Catalyst preparation. Catalysts were prepared by impregnation of $\gamma-\mathrm{Al}_{2} \mathrm{O}_{3}$ (Ketjen $000-1,5 \mathrm{E}$, pore volume $0.51 \mathrm{~cm}^{3} \mathrm{~g}^{-1}$, surface area $213 \mathrm{~m}^{2} \mathrm{~g}^{-1}$, particle size $180-300 \mu \mathrm{m}$ ) with aqueous solutions of ammonium heptamolybdate (Merck, min 99\%) or ammonium metatungstate (Koch-Light, min 99.9\%). Wet and dry impregnations were carried out using 5.5 and $0.51 \mathrm{~cm}^{3}$ solution per gram of carrier, respectively. The impregnated samples were dried at $393 \mathrm{~K}$ ( 16 h) and calcined under fluidizing conditions at $823 \mathrm{~K}$ in dry air $(2 \mathrm{~h})$.

The preparation methods for catalysts prepared via adsorption (6), gas-phase deposition (6), and impregnation of boehmite (29) have been published previously.

The $\mathrm{Re}_{2} \mathrm{O}_{7} / \gamma-\mathrm{Al}_{2} \mathrm{O}_{3}$ catalysts were prepared by dry impregnation using aqueous solutions of ammonium perrhenate (Drijfhout, 99.9\%) followed by drying at $383 \mathrm{~K}$ (16 h).

$X$-Ray diffraction. The X-ray diffraction patterns have been recorded on a Philips PW 1050-25 vertical diffractometer.

Specific surface area and pore volume measurements. The specific surface area and pore volume of the catalysts have been determined according to the BET method on a Carlo Erba Sorptomatic (nitrogen adsorption at $78 \mathrm{~K}$; area of adsorbed $\mathrm{N}_{2}$. $0.1627 \mathrm{~nm}^{2} /$ molecule $\mathrm{N}_{2}$ ). Pore volumes have been measured also via water titration.

Transition metal content determination. Mo and $W$ content of the samples has been analyzed by means of atomic absorption spectroscopy (AAS) (Perkin-Elmer 300 AAS), X-ray fluorescence (Philips $1410 \mathrm{X}$ ray spectrometer) using a borax fusion technique $(30)$, and temperature-programmed reduction; Re content was determined only by AAS and TPR.

Temperature-programmed reduction. A catalyst sample containing approximately $0.2 \mathrm{mmol}$ of transition metal ions was reduced in a stream of a hydrogen/nitrogen or a hydrogen/argon mixture (flow rate 12.5 $\mu \mathrm{mol}^{-1}$ ) from 473 to $1333 \mathrm{~K}$ at a constant heating rate of $5 \mathrm{~K} \mathrm{~min}^{-1}$ in a quartz tube (inner diameter $4.5 \mathrm{~mm}$ ).

Reduction leads to a decrease in hydrogen concentration, which was detected by a thermal conductivity cell (Fig. 1). Before a measurement the sample was preheated in air $(773 \mathrm{~K}, 1 \mathrm{~h})$, in order to be sure that all

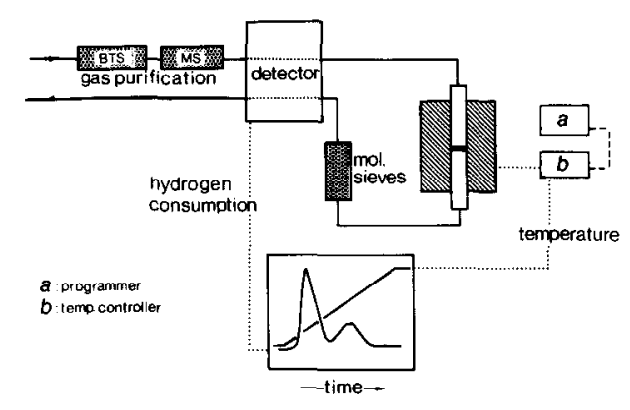

FIG. 1. Scheme of TPR apparatus. 


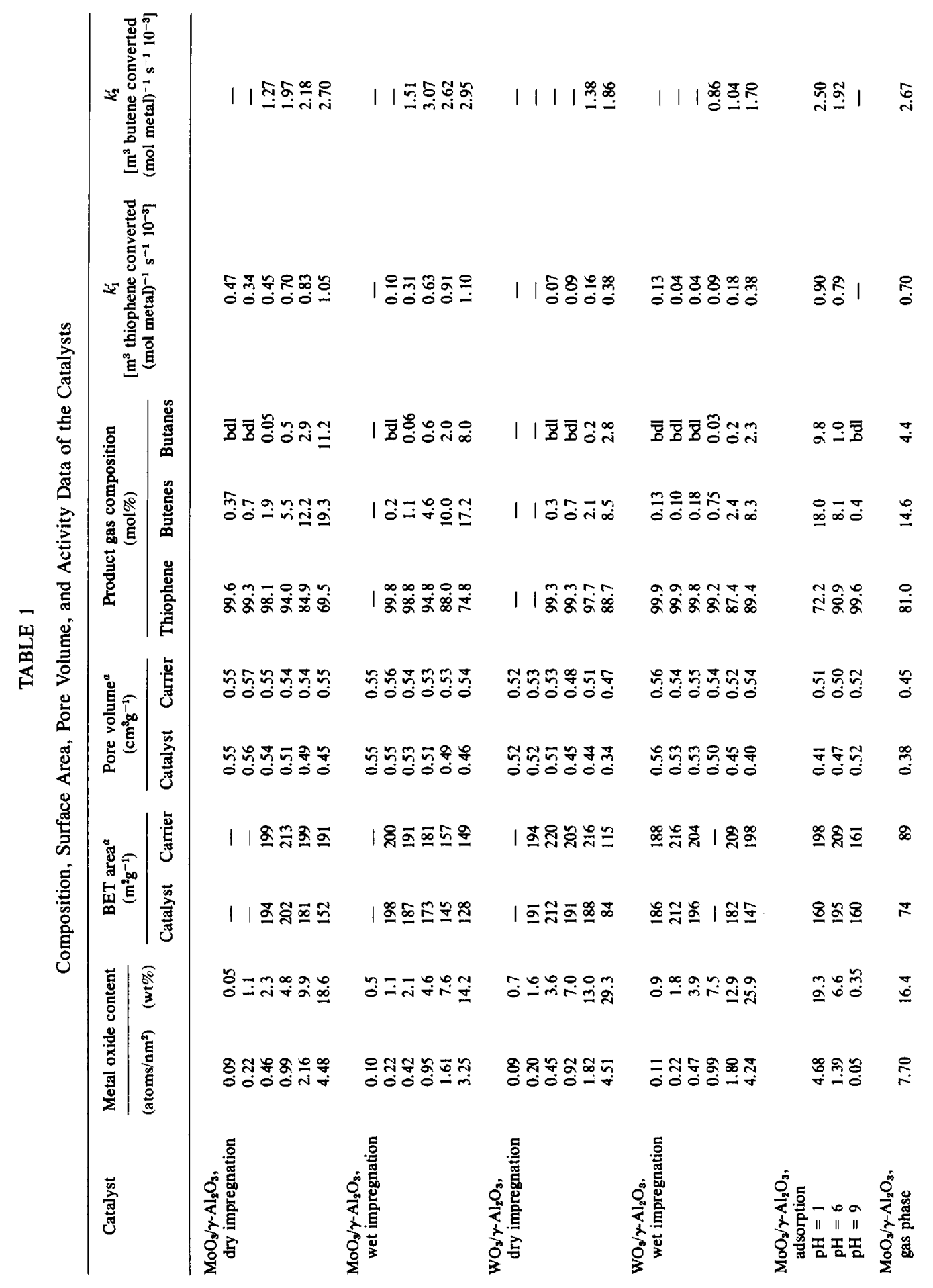




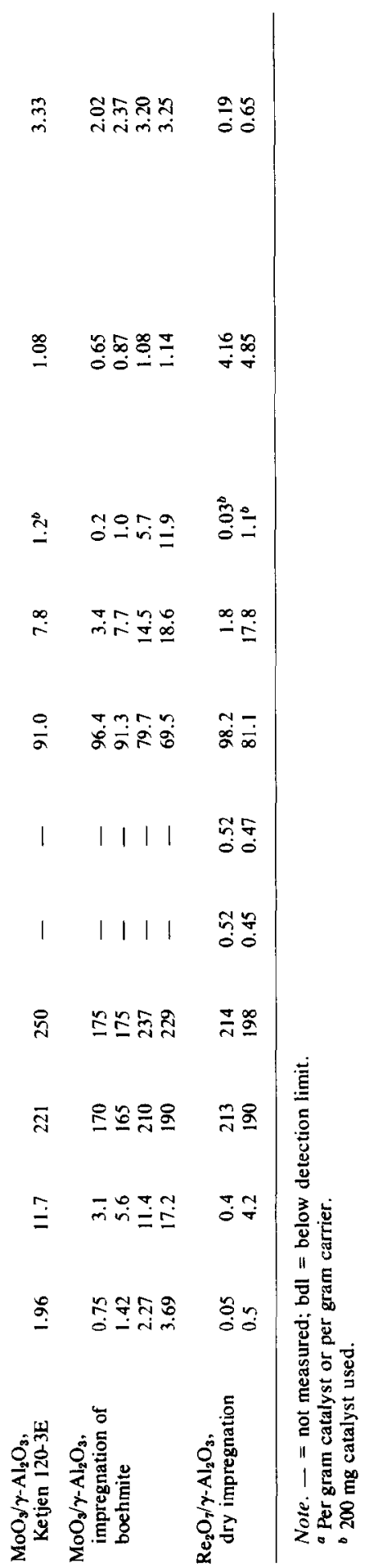

species were fully oxidized, and cooled under vacuum to $473 \mathrm{~K}$.

The $\mathrm{H}_{2} / \mathrm{N}_{2}$ mixture (Hoekloos, $99.9 \%, \mathrm{H}_{2}$ mole fraction 0.67 ) and the $\mathrm{H}_{2} /$ Ar mixture (Matheson, RP, $\mathrm{H}_{2}$ mole fraction 0.69) have been purified with a deoxygenation catalyst (BASF, R311) and molecular sieves (Merck 3A).

Activity measurements. Hydrodesulfurization experiments have been carried out in a micro-flow reactor at atmospheric pressure. The reactor was a quartz tube (inner diameter $8 \mathrm{~mm}$ ), and all other parts of the equipment consisted of stainless steel. A detailed description has been published previously $(3 I)$.

Prior to the activity test the sample (normally $0.5 \mathrm{~g}$ ) was presulfided in situ in a mixture of hydrogen and hydrogen sulfide at atmospheric pressure. The $\mathrm{H}_{2} \mathrm{~S}$ concentration was $10 \mathrm{~mol} \%$, total flow rate 42 $\mu \mathrm{mol}^{-1}$. The temperature was increased to $673 \mathrm{~K}$ by the following program: $10 \mathrm{~min}$ at $295 \mathrm{~K}$, linear temperature increase to $673 \mathrm{~K}$ in $1 \mathrm{~h}$, isothermal at $673 \mathrm{~K}$ during $2 \mathrm{~h}$. After this sulfiding procedure a mixture of hydrogen (Hoekloos, 99.9\%) and thiophene (Merck, min 99\%), with a thiophene mole fraction of $6.2 \mathrm{~mol} \%$, was fed to the reactor at a flow rate of $35 \mu \mathrm{mol}^{-1}$. Reaction products have been analyzed by gas chromatography. Hydrodesulfurization (HDS) activity and butene hydrogenation activity were calculated from analysis data obtained after runs of 2-h duration.

\section{RESULTS}

\section{Transition Metal Content}

The composition of the catalysts is shown in Table 1. The values are the average of the results from X-ray fluorescence, atomic absorption spectrometry, and temperature-programmed reduction. On the average the data of these methods agree within $10 \%$.

\section{$X-R a y$ Diffraction}

X-Ray diffraction (XRD) patterns only showed diffraction bands of the carrier. 
This means that, indeed, all catalysts are of the monolayer type.

\section{Surface Area and Pore Volume}

The BET surface areas and pore volumes, as determined by water titration, calculated per gram of catalyst, as well as per gram of carrier in the catalyst, are shown in Table 1.

\section{Temperature-Programmed Reduction}

The TPR patterns of $\mathrm{MoO}_{3}, \mathrm{Al}_{2}\left(\mathrm{MoO}_{4}\right)_{3}$, and $\mathrm{MoO}_{3} / \gamma-\mathrm{Al}_{2} \mathrm{O}_{3}$ catalysts, prepared by dry impregnation, as well as those of $\mathrm{WO}_{3}$, $\mathrm{Al}_{2}\left(\mathrm{WO}_{4}\right)_{3}$, and $\mathrm{WO}_{3} / \gamma-\mathrm{Al}_{2} \mathrm{O}_{3}$ catalysts prepared by dry impregnation, are shown in Fig. 2. The patterns of the catalysts prepared by wet impregnation are similar to those for the dry-impregnated catalysts and are therefore not shown. Between 900 and $1200 \mathrm{~K}$ some reduction of the carrier takes place. The area of this carrier peak decreases with increasing transition metal content of the catalyst. It should be noted that this decrease is due to the fact that the
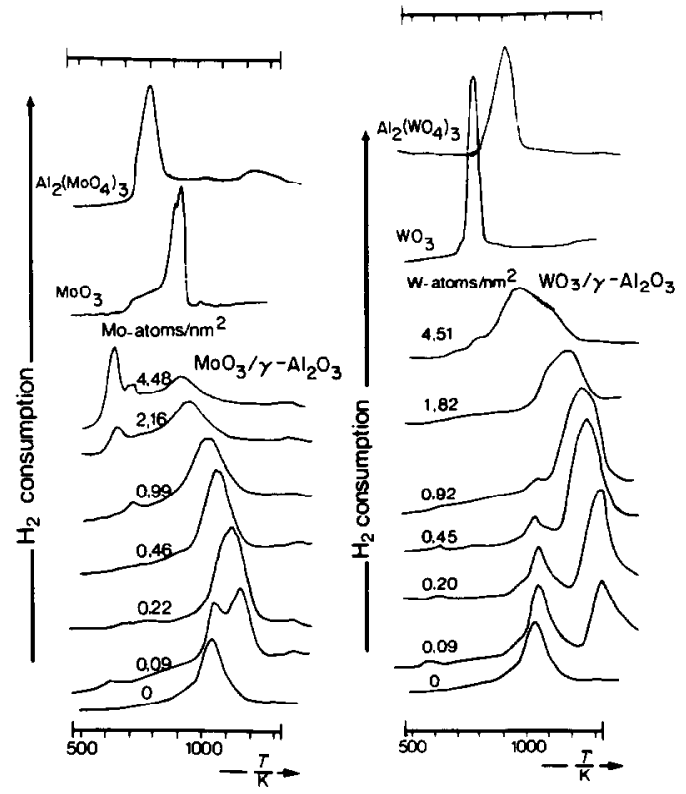

FIG. 2. TPR patterns of $\mathrm{Al}_{2}\left(\mathrm{MoO}_{4}\right)_{3}, \mathrm{MoO}_{3}$, and $\mathrm{MoO}_{3} / \gamma-\mathrm{Al}_{2} \mathrm{O}_{3}$ catalysts prepared by dry impregnation, as well as of $\mathrm{Al}_{2}\left(\mathrm{WO}_{4}\right)_{3}, \mathrm{WO}_{3}$, and $\mathrm{WO}_{3} / \gamma-\mathrm{Al}_{2} \mathrm{O}_{3}$ catalysts prepared by dry impregnation. absolute amount of transition metal in the samples has been kept constant (approx 0.2 mmol). Thus with increasing transition metal content the sample size and consequently the amount of carrier decreases.

Figure 3 shows the TPR patterns of $\mathrm{MoO}_{3} / \gamma-\mathrm{Al}_{2} \mathrm{O}_{3}$ catalysts prepared by liquidphase adsorption at various $\mathrm{pH}$ values (Figs. 3a-c) and by gas-phase adsorption

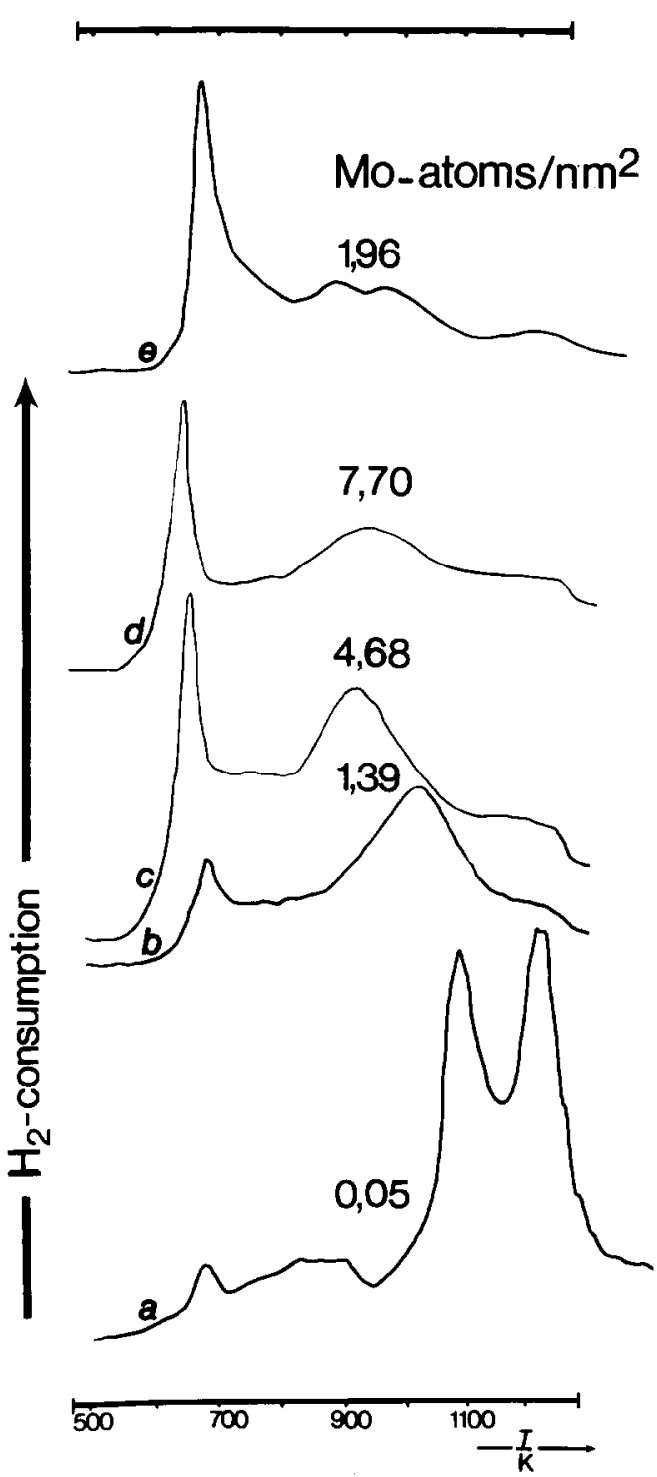

FIG. 3. TPR patterns of $\mathrm{MoO}_{3} / \gamma-\mathrm{Al}_{2} \mathrm{O}_{3}$ catalysts prepared by liquid-phase adsorption at $\mathrm{pH}=9,6$, and 1 $(a, b, c)$, gas-phase adsorption (d), and a Ketjen catalyst, type 120-3E (e). 
(Fig. 3d). In addition, the TPR patterns of a commercial catalyst (Ketjen 120-3E) are shown (Fig. 3e). The TPR patterns of catalysts prepared via impregnation of boehmite (29) are shown in Fig. 4. In Fig. 5, TPR patterns are shown of $\operatorname{Re}_{2} \mathrm{O}_{7} / \gamma-\mathrm{Al}_{2} \mathrm{O}_{3}$ catalysts and of $\mathrm{NH}_{4} \mathrm{ReO}_{4}$.

\section{Thiophene Hydrodesulfurization Activity}

Figure 6 shows for the molybdenum and tungsten catalysts the relation between thiophene hydrodesulfurization activity and the surface coverage. Due to their relatively large error the points corresponding to conversion levels below $0.5 \%$ have not been included. The reaction rate constants for hydrodesulfurization have been calculated on the basis of simplified kinetics. In this comparative study, it is assumed that the reaction is first order in thiophene. The application of a more complex kinetic scheme will not significantly change the relative order of activity of the catalysts. Thus $r_{\mathrm{HDS}}=k_{1} C_{\mathrm{T}}$, where

$r_{\mathrm{HDS}}=$ reaction rate $[(\mathrm{mol}$ thiophene converted ( $\mathrm{kg}$ catalyst) $\left.\left.{ }^{-1} \mathrm{~s}^{-1}\right)\right]$,

$k_{1}=$ first-order reaction rate constant $\left[\left(\mathrm{m}^{3}\right.\right.$ thiophene converted $(\mathrm{kg}$ catalyst) $\left.\left.{ }^{-1} \mathrm{~s}^{-1}\right)\right]$,

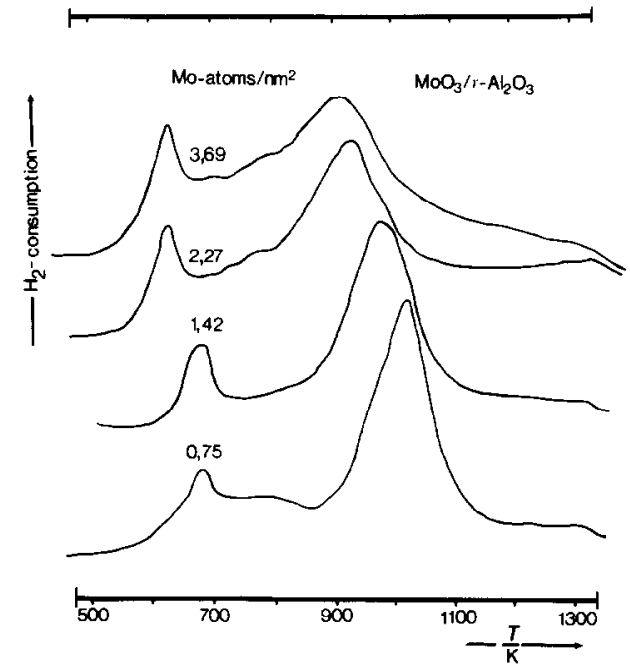

FIG. 4. TPR patterns of $\mathrm{MoO}_{3} / \gamma-\mathrm{Al}_{2} \mathrm{O}_{3}$ catalysts prepared by impregnation of boehmite.

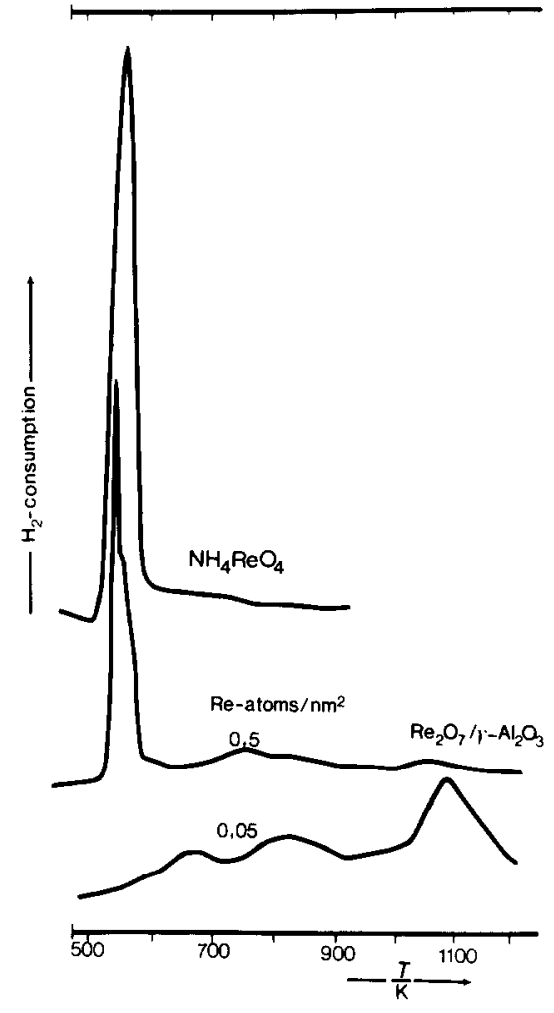

FIG. 5. TPR patterns of $\mathrm{NH}_{4} \mathrm{ReO}_{4}$ and two $\mathrm{Re}_{2} \mathrm{O}_{7} / \gamma$ $\mathrm{Al}_{2} \mathrm{O}_{3}$ catalysts.

$C_{\mathrm{T}}=$ concentration of thiophene in the reactor $\left[\left(\mathrm{mol}\right.\right.$ thiophene $\left.\left.\mathrm{m}^{-3}\right)\right]$.

It is reasonable to expect that $r$ and $k$ are

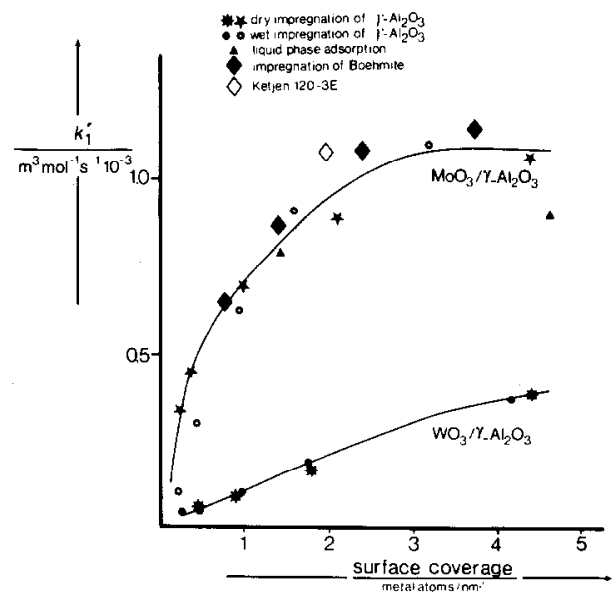

FIG. 6. Reaction rate constant for the hydrodesulfurization of thiophene as a function of the average carrier surface coverage for presulfided catalysts. 
proportional to the active-site concentration. This concentration cannot easily be determined, but the simplest model is that it is proportional to the metal concentration. Therefore, to correct for the variation in active-site concentration, the HDS activity of each catalyst is expressed as the reaction rate constant divided by the number of moles of transition metal per kilogram of catalyst: $k_{1}^{\prime}=k_{1} /[\mathrm{mol}$ transition metal $(\mathrm{kg}$ catalyst) ${ }^{-1} \mathrm{~s}^{-1}$ ] (Fig. 6, Table 1). In Table 1 also the $k_{1}^{\prime}$ values for the rhenium catalysts are given. Generally the activity, which declines with time, is fairly stable after $2 \mathrm{~h}$; therefore, reaction rate constants have been calculated based on thiophene conversions measured after $2 \mathrm{~h}$. However, qualitatively the same picture is obtained when another time is chosen.

\section{Hydrogenation Activity}

The reaction rate constant, $k_{2}$, for the hydrogenation of butene can be calculated from the product composition. For this calculation it is assumed that butene is a primary product from the hydrodesulfurization of thiophene and that its hydrogenation to butane is a first-order consecutive reaction. Thus $r_{\mathrm{HYDR}}=k_{2} C_{\mathrm{B}}$, where

$r_{\mathrm{HYDR}}=$ reaction rate $[(\mathrm{mol}$ butene converted $\left(\mathrm{kg}\right.$ catalyst) $\left.\left.{ }^{-1} \mathrm{~s}^{-1}\right)\right]$,

$k_{2}=$ reaction rate constant $\left[\left(\mathrm{m}^{3}\right.\right.$ butene converted ( $\mathrm{kg}$ catalyst) $\left.\left.{ }^{-1} \mathrm{~s}^{-1}\right)\right]$

$C_{\mathrm{B}}=$ concentration of butene in the reactor $\left[\left(\mathrm{mol}\right.\right.$ butene $\left.\left.\mathrm{m}^{-3}\right)\right]$.

The hydrogenation rate constant divided by the number of moles of transition metal per kilogram of catalyst ( $\left.k_{2}^{\prime}\right)$ is plotted as a function of the carrier surface coverage (Fig. 7). $k_{2}^{\prime}$ values for the rhenium catalysts are given in Table 1.

\section{DISCUSSION}

\section{Surface Area and Pore Volume Measurements}

Surface area and pore volume measurements (Table 1) indicate that, in general, im-

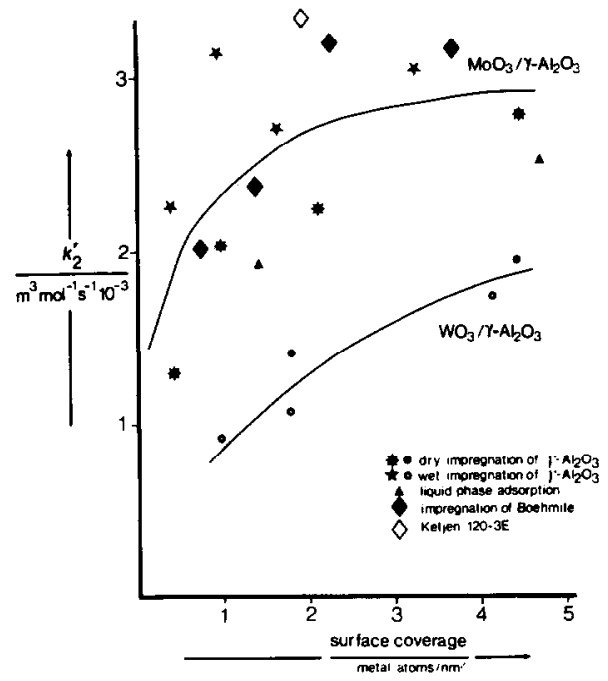

FIG. 7. Reaction rate constant for hydrogenation of butene as a function of the average carrier surface coverage for presulfided catalysts.

pregnation and calcination have only slightly affected the $\gamma-\mathrm{Al}_{2} \mathrm{O}_{3}$ texture.

Liquid-phase adsorption at $\mathrm{pH}=9$ results in a significant reduction in surface area in spite of a relatively low surface coverage. This is due to some dissolution of the carrier. At $\mathrm{pH}=6$ and $\mathrm{pH}=1$ no such effect is observed.

The surface area of the catalyst prepared by gas adsorption is strongly decreased, which is due to the severe preparation conditions ( $873 \mathrm{~K}, 5$ days).

The preparation method via impregnation of boehmite (29) is apparently less reproducible than the $\gamma$-alumina impregnation method in the sense that no reasonable relation between molybdenum content and surface area exists.

\section{Temperature-Programmed Reduction}

$\mathrm{MoO}_{3} / \gamma-\mathrm{Al}_{2} \mathrm{O}_{3}$ catalysts prepared by impregnation of $\gamma-\mathrm{Al}_{2} \mathrm{O}_{3}$ (Fig. 2). TPR patterns of these catalysts and of $\mathrm{MoO}_{3}$ have been published previously $(2 l)$. The $\mathrm{MoO}_{3}$ pattern reported here differs from the pattern in Ref. (21). The difference is caused by the application of another reducing gas mixture, viz., $\mathrm{H}_{2} / \mathrm{Ar}$, instead of $\mathrm{H}_{2} / \mathrm{N}_{2}$. Using $\mathrm{H}_{2} / \mathrm{Ar}$, the formation of molybdenum ni- 
tride from molybdenum metal atoms and nitrogen is avoided. This reaction leads in the case of $\mathrm{H}_{2} / \mathrm{N}_{2}$ to a negative TPR peak after the reduction of molybdenum trioxide to the metal. At high temperature the nitride is decomposed resulting in an extra (positive) TPR peak. For the catalysts and aluminum molybdate this is not observed; $\mathrm{H}_{2} / \mathrm{Ar}$ and $\mathrm{H}_{2} / \mathrm{N}_{2}$ give similar TPR patterns.

It can be seen from Fig. 2 that the reducibility of the $\mathrm{MoO}_{3} / \gamma-\mathrm{Al}_{2} \mathrm{O}_{3}$ catalysts is connected with surface coverage. The average reduction temperature decreases with increasing surface coverage. This shift may reflect the heterogeneity of the $\gamma$-alumina surface. It implies that the interaction between Mo species and the carrier is stronger at lower surface coverages. It is also possible that the shift is caused by differences in degree of aggregation, which increases with surface coverage (32).

From TPR alone it cannot be decided, at present, whether lower reduction temperatures are related to an increase of aggregation or a decrease of interaction. It can also not be cxcluded that both explanations are valid because, when the interaction between Mo species and the alumina surface is stronger, the degree of aggregation might be lower. At higher contents an additional TPR band, which can be ascribed to a Mo compound having another structure, is observed at a lower temperature. This band may also be considered as indicative for the formation of a second molybdate layer on top of the, not yet completed, first monolayer. Since the interaction between these two layers will be weaker than that between the first layer and the carrier, it is conceivable that it is reduced at a lower temperature.

$\mathrm{MoO}_{3} / \gamma-\mathrm{Al}_{2} \mathrm{O}_{3}$ catalysts prepared by other methods. As can be seen from Table 1 the $\mathrm{pH}$ of the liquid phase has a large influence on the molybdenum content of the catalysts prepared by liquid-phase adsorption. Figure 3 shows that at comparable surface coverage the TPR patterns are similar to the patterns of the catalyst prepared by dry and wet impregnations (Fig. 2). The catalysts prepared by liquid-phase adsorption have been described as monolayer catalysts (6). If the low-temperature reduction band is ascribed to the building up of molybdate layers, it is clear that also this method does not lead to a full monolayer of molybdate species on alumina. This applies also to the catalyst prepared by gas-phase adsorption. Due to the preparation method used, the average surface coverage in this catalyst is $7.7 \mathrm{Mo}$ atoms $/ \mathrm{nm}^{2}$ at a $\mathrm{MoO}_{3}$ content of $11.7 \mathrm{wt} \% \mathrm{MoO}_{3}$. Although this value is above the theoretical monolayer value (about 6 Mo atoms $/ \mathrm{nm}^{2}$ ) no bulk compounds are observed by XRD or Raman spectroscopy. This observation supports the assignment of the low-temperature band to reduction of multilayers. The TPR pattern of the commercial catalyst also resembles the patterns of the other catalysts. It is evident that the molybdate in this catalyst is less well dispersed; a considerable amount of the molybdate is reduced at a low temperature.

It can be seen from Fig. 4 that preparation of the catalysts via impregnation of boehmite also does not give rise to fundamental changes in the TPR patterns.

$\mathrm{WO}_{3} / \gamma-\mathrm{Al}_{2} \mathrm{O}_{3}$ catalysts. In the TPR patterns of the $\mathrm{WO}_{3} / \gamma-\mathrm{Al}_{2} \mathrm{O}_{3}$ catalysts (Fig. 2) essentially only one broad reduction band is observed for all catalysts. Reduction, being very difficult at low $W$ contents, becomes easier at increasing $W$ content. The fact that, at comparable surface coverage, the reduction of the tungstate species is less easily performed than that of the molybdate species may reflect a stronger interaction between these species and the support. This is also evident from the observation that in these catalysts a second (low-temperature) band is never observed. As stated above, this may be considered as an indication that, up to a surface coverage of $5 \mathrm{~W}$ atoms $/ \mathbf{n m}^{2}$, the monolayer is completed before a second layer is formed. Apparently the preparation method, viz., dry or wet impregnation, has no significant influence 
on the structure of the catalysts, since the TPR patterns at comparable surface coverage are similar.

$\mathrm{Re}_{2} \mathrm{O}_{7} / \gamma-\mathrm{Al}_{2} \mathrm{O}_{3}$ catalysts. The reduction characteristics of the $\mathrm{Re}_{2} \mathrm{O}_{7} / \gamma-\mathrm{Al}_{2} \mathrm{O}_{3}$ catalysts deviate from those of $\mathrm{MoO}_{3} / \gamma-\mathrm{Al}_{2} \mathrm{O}_{3}$ and $\mathrm{WO}_{3} / \gamma-\mathrm{Al}_{2} \mathrm{O}_{3}$, as has been reported before (26). As can be seen from Fig. 5, the TPR pattern of the catalyst with a surface coverage of $0.5 \mathrm{Re}$ atoms $/ \mathrm{nm}^{2}$ resembles the pattern of $\mathrm{NH}_{4} \mathrm{ReO}_{4}$. This has been observed also in the Raman spectra (33) and it may be due to a weak interaction between the Re compounds and the carrier. At very low surface coverage $\left(0.05 \mathrm{Re}\right.$ atoms $\left./ \mathrm{nm}^{2}\right)$, apart from a band at $900-1200 \mathrm{~K}$ due to reduction of the carrier, two $\mathrm{Re}$ bands are present in the TPR pattern. The relatively high reduction temperature indicates a stronger interaction between the carrier and the Re-surface compounds.

\section{Thiophene Hydrodesulfurization Activity}

$\mathrm{MoO}_{3} / \gamma-\mathrm{Al}_{2} \mathrm{O}_{3}$ catalysts. As shown in Fig. 6, the efficiency for thiophene hydrodesulfurization, being very low at low surface coverage, increases markedly with increasing Mo content and levels off at a surface coverage of 4-5 Mo atoms $/ \mathrm{nm}^{2}$ for the sulfided catalysts prepared by dry and wet impregnations of $\gamma-\mathrm{Al}_{2} \mathrm{O}_{3}$. This is rather close to the coverage where theoretically a full monolayer is reached (area per Mo atom: $\left.0.17 \mathrm{~nm}^{2}\right)(6)$.

These results are qualitatively in good agreement with measurements on prereduced initially oxidic catalysts (34). They may reflect both the heterogeneity of the $\gamma$ alumina surface as well as a strong interaction between the oxidic molybdenum compounds and the carrier. Therefore, especially in the low concentration range, the formation of $\mathrm{MoS}_{2}$, which is almost generally accepted to be the actual active phase (35), is hampered.

It is striking that at comparable surface coverage, variations in preparation method do not affect HDS activity.

$\mathrm{WO}_{3} / \gamma-\mathrm{Al}_{2} \mathrm{O}_{3}$ catalysts. As can be seen from Fig. 6, $\mathrm{WO}_{3} / \gamma-\mathrm{Al}_{2} \mathrm{O}_{3}$ catalysts are considerably less active for thiophene hydrodesulfurization than the corresponding $\mathrm{MoO}_{3} /$ $\gamma-\mathrm{Al}_{2} \mathrm{O}_{3}$ catalysts. The shapes of the two curves, however, are similar. This indicates that we are dealing with essentially the same system. The difference in HDS properties is most likely caused by the fact that the oxidic tungsten species are more strongly bonded to the support, and thus less readily sulfided (reduced), as has also been concluded from the TPR patterns.

$\mathrm{Re}_{2} \mathrm{O}_{7} / \gamma-\mathrm{Al}_{2} \mathrm{O}_{3}$ catalysts. The efficiency of sulfided $\mathrm{Re}_{2} \mathrm{O}_{7} / \gamma-\mathrm{Al}_{2} \mathrm{O}_{3}$ is strikingly high (Table 1). Moreover, the efficiency does not seem to depend very much on the surface coverage.

\section{Butene Hydrogenation Activity}

Figure 7 shows that the activity increases with surface coverage and that Mo-based catalysts are more active than the corresponding W-based catalysts. From comparison of HDS and hydrogenation rate constants it can be concluded that $\mathrm{WO}_{3} / \gamma-\mathrm{Al}_{2} \mathrm{O}_{3}$ catalysts are relatively better hydrogenation catalysts than $\mathrm{MoO}_{3} / \gamma-\mathrm{Al}_{2} \mathrm{O}_{3}$. This is

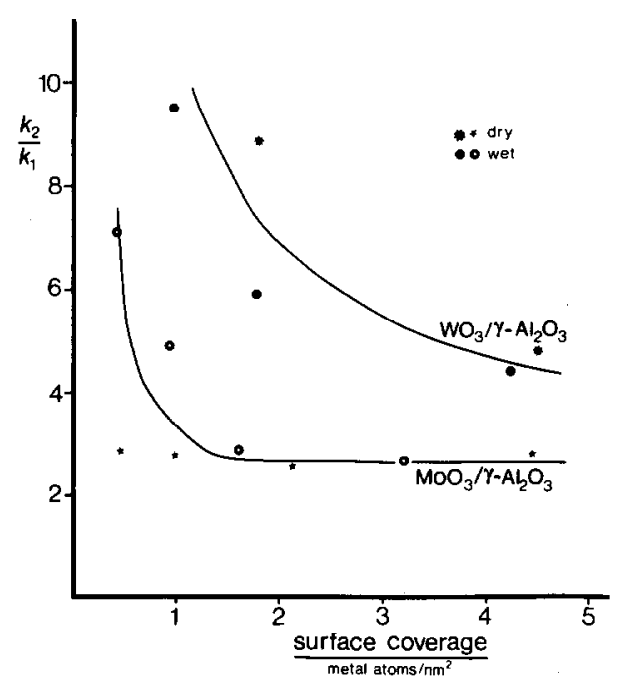

FIG. 8. Ratio between reaction rate constant for hydrogenation of butene and hydrodesulfurization of thiophene as a function of the average carrier surface coverage, for $\mathrm{MoO}_{2} / \gamma-\mathrm{Al}_{2} \mathrm{O}_{3}$ and $\mathrm{WO}_{3} / \gamma-\mathrm{Al}_{2} \mathrm{O}_{3}$ catalysts, prepared by dry or wet impregnation. 
shown in Fig. 8, where the ratio between the rate constants for hydrogenation and HDS is plotted as a function of the average surface coverage. These relatively better hydrogenation properties have been reported earlier by Ahuja et al. (36) and de Beer et al. (37). The $\mathrm{Re}_{2} \mathrm{O}_{7} / \gamma-\mathrm{Al}_{2} \mathrm{O}_{3}$ catalysts, however, behave quite differently; hydrogenation activity is very low with respect to HDS activity (Table 1). Thus, the application of $\mathrm{Re}_{2} \mathrm{O}_{7} / \gamma-\mathrm{Al}_{2} \mathrm{O}_{3}$ catalysts may be preferable in processes requiring high hydrodesulfurization selectivity. On the other hand, when, e.g., in the case of heavy feeds, hydrocracking and hydrogenation reactions during hydrodesulfurization are required, $\mathrm{WO}_{3} / \gamma-\mathrm{Al}_{2} \mathrm{O}_{3}$ catalysts are to be preferred.

\section{Correlation between Hydrodesulfurization} and Hydrogenation Activity and Reducibility

In order to correlate activity and reducibility both have to be quantified. HDS activity is easily defined by means of the reaction rate constant $k_{1}^{\prime}$ from Table 1 . Reducibility can be characterized in several ways, e.g., the temperature of reduction onset or the average reduction temperature. In this study the reducibility is arbitrarily characterized by the temperature at which $50 \%$ of the transition metal species is reduced; other characterization methods lead to the same conclusions.

In Fig. 9 the activity for HDS is plotted as a function of the average reduction temperature. It is clear that a correlation exists and that the Mo- and W-based systems behave analogously and are complementary. HDS activity increases with decreasing reduction temperature. This suggests that reduction of the transition metal compounds is a crucial step in the transformation of the oxidic precursor catalyst into the sulfided catalyst. The markedly high reaction rate constant for $\mathrm{Re}_{2} \mathrm{O}_{7} / \gamma-\mathrm{Al}_{2} \mathrm{O}_{3}$ catalysts (Table 1) corresponds very well with their good reducibility. TPR thus appears to be a promising technique which can be applied for a preliminary screening of the oxidic HDS catalysts.

In Fig. 10 the relation between the reaction rate constant for hydrogenation and the average reduction temperature is visualized for the molybdenum and tungsten catalysts. Clearly also the hydrogenation activity increases with decreasing reduction temperature. This is consistent with the fact that in hydrogenation the oxidation state is an important parameter (38); generally better hy-

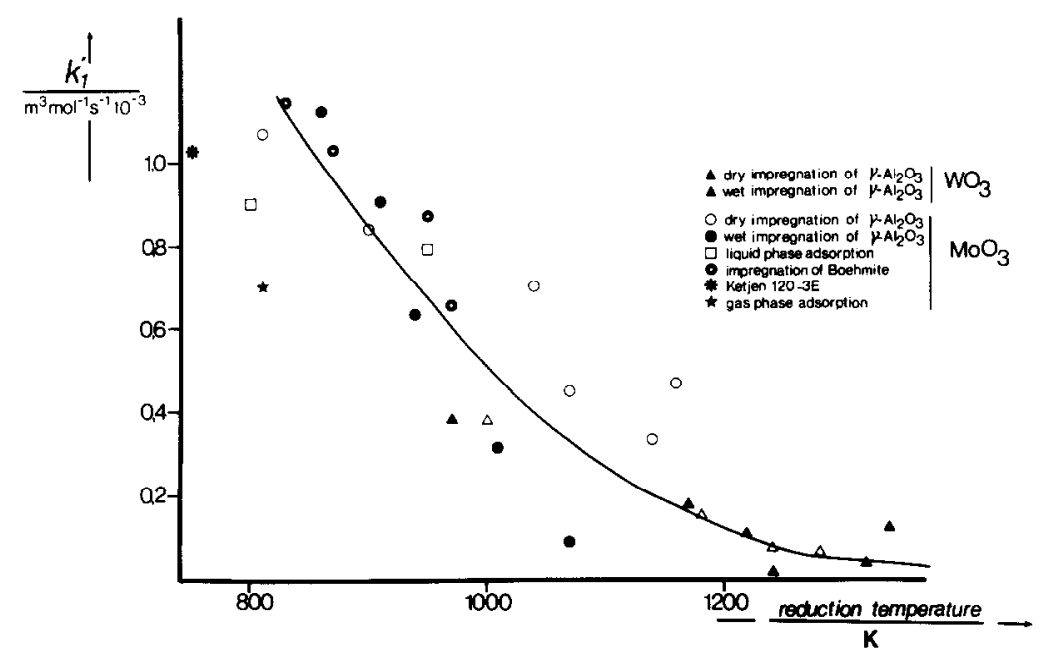

FIG. 9. Relation between the reaction rate constant for hydrodesulfurization of thiophene of sulfided $\mathrm{MoO}_{3} / \gamma-\mathrm{Al}_{2} \mathrm{O}_{3}$ and $\mathrm{WO}_{3} / \gamma-\mathrm{Al}_{2} \mathrm{O}_{3}$ catalysts and the average reduction temperature. 


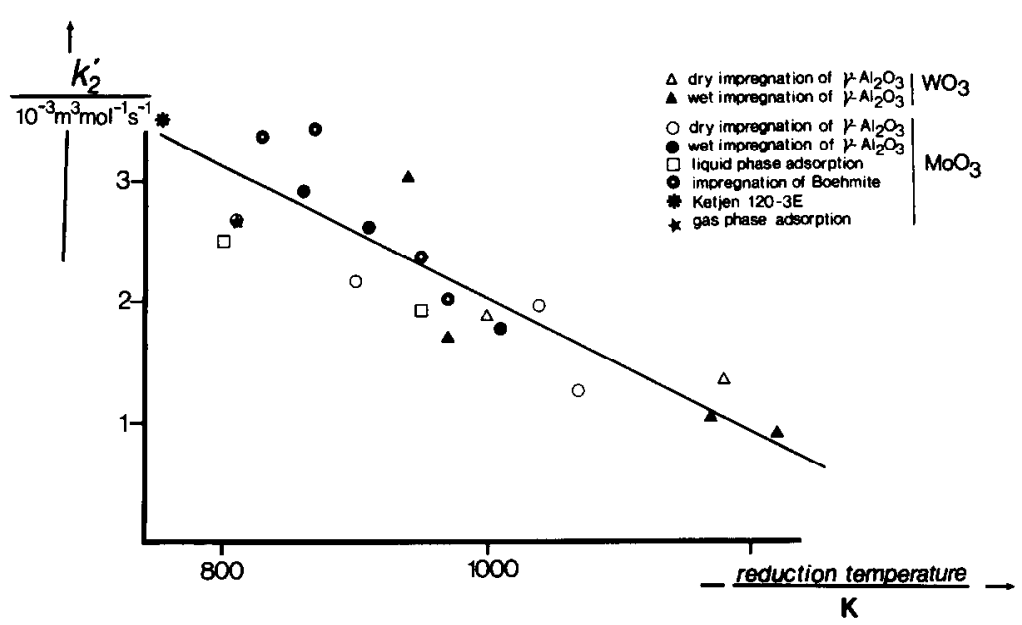

FIG. 10. Relation between the reaction rate constant for hydrogenation of butene of sulfided $\mathrm{MoO}_{3} / \gamma$ $\mathrm{Al}_{2} \mathrm{O}_{3}$ and $\mathrm{WO}_{3} / \gamma-\mathrm{Al}_{2} \mathrm{O}_{3}$ catalysts and the average reduction temperature.

drogenation properties are related to low oxidation states.

\section{CONCLUSIONS}

1. For $\mathrm{MoO}_{3} / \gamma-\mathrm{Al}_{2} \mathrm{O}_{3}$ and $\mathrm{WO}_{3} / \gamma-\mathrm{Al}_{2} \mathrm{O}_{3}$, catalysts prepared by dry and wet impregnations give essentially the same results.

2. A correlation exists between the reducibility of oxidic $\mathrm{MoO}_{3} / \gamma-\mathrm{Al}_{2} \mathrm{O}_{3}$ and $\mathrm{WO}_{3} / \gamma$ $\mathrm{Al}_{2} \mathrm{O}_{3}$ catalysts prepared by dry and wet impregnations, and the hydrodesulfurization activity of the sulfided samples. The higher the reducibility, the higher the hydrodesulfurization activity.

3. This correlation also holds for $\mathrm{MoO}_{3} /$ $\gamma-\mathrm{Al}_{2} \mathrm{O}_{3}$ catalysts prepared by other methods, viz., ion exchange, gas-phase adsorption, and impregnation of boehmite.

4. Butene hydrogenation activity of sulfided $\mathrm{MoO}_{3} / \gamma-\mathrm{Al}_{2} \mathrm{O}_{3}$ and $\mathrm{WO}_{3} / \gamma-\mathrm{Al}_{2} \mathrm{O}_{3}$ catalysts also correlates with reducibility. The correlation is qualitatively the same as that for hydrodesulfurization. For $\operatorname{Re}_{2} \mathrm{O}_{7} / \gamma-$ $\mathrm{Al}_{2} \mathrm{O}_{3}$ catalysts this is not the case.

5 . The ratio between hydrogenation activity and hydrodesulfurization activity decreases in the order $\mathrm{W} \rightarrow \mathrm{Mo} \rightarrow \mathrm{Re}$.

6. TPR is a time-saving preliminary screening technique for unpromoted welldispersed hydrodesulfurization catalysts.

\section{AC KNOWLEDGMENTS}

The authors thank Ir. A. C. Zwaga, Dr. F. Roozeboom (Twente University of Technology), Dr. M. Ternan (Canmet), and Akzo Chemie B. V., Ketjen Catalysts, for provision of catalysts. Thanks are also due to Dr. B. Koch and Mr. W. Molleman (Department of X-Ray Spectrometry and Diffractometry, University of Amsterdam), to the Chemical Analysis Department of the Twente University of Technology, Enschede, and to Mrs. M. C. Mittelmeijer-Hazeleger for TPR measurements.

\section{REFERENCES}

1. Weisser, O., and Landa, S., "Sulphide Catalysts, Their Properties and Applications." Pergamon, New York, 1973.

2. Lipsch, J. M. J. P., and Schuit, G. C. A., J. Catal. 15, 174 (1969).

3. Ashley, J. H., and Mitchell, P. C. H., J. Chem. Soc. A, 2730 (1969).

4. Asmolov, G. N., and Krylov, O. V., Kinet. Katal. 11, 1028 (1970).

5. Schuit, G. C. A., and Gates, B. C., AIChE J. 19, 417 (1973).

6. Sonnemans, J., and Mars, P., J. Catal. 31, 209 (1973).

7. Massoth, F. E., J. Catal. 30, 203 (1973).

8. Giordano, N., Bart, J. C. J., Vaghi, A., Castellan, A., and Martinotti, G., J. Catal. 36, 81 (1975).

9. Brown, F. R., Makovsky, L. E., and Rhee, K. H., J. Catal. 50, 162 (1977).

10. Stork, W. H. J., and Pott, G. T., Recl. Trav. Chim. Pays-Bas 96, M105 (1977). 
11. Thomas, R., Moulijn, J. A., and Kerkhof, F. P. J. M., Recl. Trav. Chim. Pays-Bas 96, M134 (1977).

12. Medema, J., van Stam, C., de Beer, V. H. J., Konings, A. J. A., and Koningsberger, D. C., J. Catal. 53, 186 (1978).

13. Payen, E., Barbillat, J., Grimblot, J., and Bonnelle, J. P., Spectrosc. Lett. 11, 997 (1978).

14. Voro'bev, L. N., Kalinevich, A.Yu., and Talipov, G.Sh., Kinet. Katal. 19, 737 (1978).

15. Knözinger, H., and Ratnasamy, P., Catal. Rev. Sci. Eng. 17, 31 (1978).

16. Stork, W. H. J., Coolegem, J. G. F., and Pott, G. T., J. Catal. 32, 497 (1978).

17. Gajardo, P., Ph.D. thesis, Louvain-la-Neuve, 1978.

18. Cheng, C. P., and Schrader, G. L., J. Catal. 60, 276 (1979).

19. Delmon, B., in "Proceedings, 3rd International Conference on the Chemistry and Uses of Molybdenum" (H. F. Barry and P. C. H. Mitchell, Eds.), p. 73. Climax Molybdenum Company, Ann Arbor, Mich., 1979.

20. Iannibello, A., Marengo, S., Trifirò, F., and Villa, P. L., "Preparation of Catalysts 2" (B. Delmon, P. Grange, P. Jacobs, and P. Poncelet, Eds.), p. 65. Elsevier, Amsterdam, 1979.

21. Thomas, R., Mittelmeijer-Hazeleger, M. C., Kerkhof, F. P. J. M., Moulijn, J. A., Medema, J., and de Beer, V. H. J., in "Proceedings, 3rd International Conference on the Chemistry and Uses of Molybdenum" (H. F. Barry and P. C. H. Mitchell, Eds.), p. 85. Climax Molybdenum Company, Ann Arbor, Mich., 1979.

22. Jeziorowski, H., and Knözinger, H., J. Phys. Chem. 83, 1166 (1979).

23. Hall, W. K., and Massoth, F. E., J. Catal. 34, 41 (1979).

24. Thomas, R., Kerkhof, F. P. J. M., Moulijn, J. A.,
Medema, J., and de Beer, V. H. J., J. Catal. 61, 559 (1980).

25. Nag, N. K., Fraenkel, D., Moulijn, J, A., and Gates, B. C., J. Catal. 66, 162 (1980).

26. Kerkhof, F. P. J. M., Ph.D. thesis, p. 138. University of Amsterdam, 1979.

27. Haher, I., in "Proceedings, 2nd International Conference on the Chemistry and Uses of Molybdenum" (P. C. H. Mitchell and A. Seaman, Eds.), p. 119. Climax Company, Oxford, England, 1976.

28. Arnoldy, P., and Moulijn, J. A., to be published.

29. Parson, B. I., and Ternan, M., in "Proceedings, 6th International Congress on Catalysis, London, 1976" (G. C. Bond, P. B. Wells, and F. C. Tompkins, Eds.), Vol. 2, p. 965. The Chemical Society, London, 1977.

30. van Willigen, J. H. H. G., Kruidhof, H., and Dahmen, E. A. M. F., Talanta 18, 450 (1971).

31. deBeer, V. H. J., van Sint Fiet, T. H. M., van Engelen, J. R., van Haandel, A. C. Wolfs, M. W. J., Amberg, C. H., and Schuit, G. C. A., J. Catal. 27, 357 (1974).

32. Thomas, R., de Beer, V. H. J., and Moulijn, J. A., Bull. Soc. Chim. Belg. 90, 1349 (1981).

33. Kerkhof, F. P. J. M., Moulijn, J. A., and Thomas, R., J. Catal. 56, 279 (1979).

34. de Beer, V. H. J., van der Aalst, M. J. M., Machiels, C. J., and Schuit, G. C. A., J. Catal. 43, 78 (1976).

35. Gates, B. C., Katzer, J. R., and Schuit, G. C. A., "Chemistry of Catalytic Processes," Chap. 5. McGraw-Hill, New York, 1979.

36. Ahuja, S. P., Derrien, M. C., and Le Page, J. F., Ind. Eng. Chem. 9, 272 (1970).

37. de Beer, V. H. J., Dahlmans, J. G. J., and Smeets, J. G. M., J. Catal. 42, 467 (1976).

38. Lombardo, E. A., Houalla, M., and Hall, W. K., J. Catal. 51, 256 (1978). 